\title{
A NEW SPECIES OF THE GENUS Halicyclops (Copepoda, Cyclopoida, Cyclopidae) FROM FRESHWATER IN CENTRAL VIETNAM
}

\author{
Tran Duc Luong ${ }^{1 *}$, Le Danh Minh ${ }^{2}$, Ho Thanh Hai ${ }^{1}$ \\ ${ }^{1}$ Institute of Ecology and Biological Resources, VAST \\ ${ }^{2} \mathrm{Ha}$ Tinh University
}

\begin{abstract}
A new cyclopoid species, Halicyclops songsonensis Tran, Le \& Ho, sp. n., from the Son River, Quang Binh Province, Central Vietnam is described. The new species is distinguished from its other congeners by having the spine formula of $3: 4: 4: 3$ on P1-P4, lateral angular protuberances on the genital double-somite, a serrate hyaline frill of pre-anal somite slightly larger on dorsal part than that on lateral and ventral parts, relatively long caudal rami, spiniform seta of proximalmost seta on P2-P3 Enp3 and showing the round/oval integumental windows on cephalothorax and two next prosomites.
\end{abstract}

Keywords: Copepods, Halicyclopinae, taxonomy, new species, freshwater.

Citation: Tran Duc Luong, Le Danh Minh, Ho Thanh Hai, 2016. A new species of the genus Halicyclops (Copepoda, Cyclopoida, Cyclopidae) from freshwater in Central Vietnam. Tap chi Sinh hoc, 38(4): 449-457. DOI: $10.15625 / 0866-7160 / \mathrm{v} 38 \mathrm{n} 4.9032$.

*Correspoding author: tranducluongiebr@gmail.com.

Received 19 December 2016, accepted 26 December 2016

\section{INTRODUCTION}

Halicyclops Norman, 1903 is a cosmopolitan genus of cyclopoid copepods of the subfamily Halicyclopinae. It is widely distributed in different kinds of surface brackish water bodies, tidal pools, lagoons and estuarine waters, anchialine caves, sinkholes, interstitial and sandy beaches habitats, as well as ponds and marshes (Chang, 2012; Pesce, 2016).

To date, a total of 95 species and subspecies have been known (Walter \& Boxshall, 2015). Most of them are planktonic and inhabiting chiefly coastal brackish water habitats. However, only several species have been reported as exclusive freshwater forms, for example $H$. sinensis from China, $H$. blachei from Cambodia, H. aberrans, H. lindbergi and H. dussarti from Brazil (Rocha, 1995; Pesce, 2016). Some exceptional species are stygophilic, inhabiting different grounwater habitats, such as anchialine caves, sinkholes and interstitial media. Some Halicyclops species live in symbiosis with various benthic invertebrates such as polychaetes and mud lobster (Ueda \& Nagai, 2012; Pesce, 2016).
In Vietnam, the genus Halicyclops has yet been poorly studied. Only one brackish water species, Halicyclops aequareus (Fischer), has been recorded from estuarine waters of the $\mathrm{Ca}$ Rive, Nghe An Province (Ho \& Tran, 2007). Here we describe a new freshwater species of the genus Halicyclops.

\section{MATERIALS AND METHODS}

Specimens were collected from the Son riverside in the Phong Nha-Ke Bang National Park, Quang Binh Province (fig. 1), using a 80 $\mu \mathrm{m}$ mesh-sized plankton net. Samples were fixed and stored in 70\% ethanol. In the laboratory, specimens were dissected under an Olympus SZ61 stereomicroscope at $40-100 \mathrm{X}$ magnifications and mounted in glycerol or lactophenol. The mounted specimens were examined under a differential interference contrast microscope (Olympus $\mathrm{CH} 40$ ) at 4001000X magnifications. All drawings were made using a camera lucida attached to the Olympus microscope (CH40) at 200-1000X magnifications.

Type specimens (holotype and paratypes) and additional materials were deposited in the 
Institute of Ecology and Biological Resources (IEBR), Ha Noi, Vietnam. Morphological terminology generally followed to that of Huys \& Boxshall (1991).

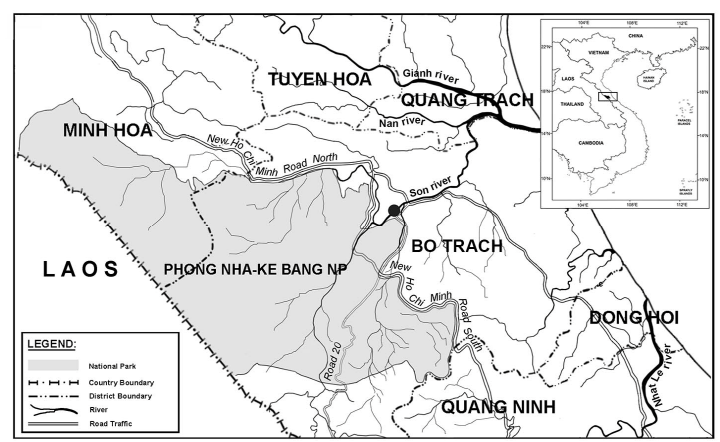

Figure 1. Sampling location of $H$. songsonenis sp. n. in the Son river, Quang Binh Province, Central Vietnam

The following abbreviations are used, where required, throughout the text and figures: Enp = endopod; Exp = exopod; P1-P6 = swimming legs 1-6.

\section{RESULTS AND DISCUSSION}

\section{Systematics}

\section{Subfamily Halicyclopinae Kiefer, 1927}

Genus Halicyclops Norman, 1903

Halicyclops songsonensis Tran, Le \& Ho, sp. n.

\section{Type material}

Holotype: adult female, dissected and mounted on two slides (IEBR-COP3250-3251); Paratypes: adult male, dissected and mounted on one slide (IEBR-COP3252); two females, dissected and mounted on two slides (IEBRCOP3253-3254), one male, dissected and mounted on one slide (IEBR-COP3255); two dissected females and one dissected male were stored in $70 \%$ ethanol (IEBR-COPAED04.14.023). All specimens were collected from type locality on 21 April 2014.

\section{Additional materials}

20 females and 4 males from type locality were stored in $70 \%$ ethanol (IEBR-COPAED04.14.024).

\section{Type locality}

The Son river, Phong Nha-Ke Bang National Park, Quang Binh Province, Central Vietnam is at $17^{\circ} 35^{\prime} 11.6^{\prime \prime} \mathrm{N}-106^{\circ} 16^{\prime} 44.2^{\prime \prime} \mathrm{E}$. Physical and chemical characteristics of water in the river on 21 April 2014 were: water temperature $25.8^{\circ} \mathrm{C} ; \mathrm{pH} 7.88$; DO $8.05 \mathrm{mg} / \mathrm{L}$; water hardness $\left(\mathrm{CaCO}_{3}\right) 136 \mathrm{mg} / \mathrm{L}$; electrical conductivity $275 \mu \mathrm{S} / \mathrm{cm}$; salinity $0.00 \%$; depths between 0.5-1.5 m. This area was covered with aquatic plants, such as Potamogeton gaudichaudii Cham \& Schlecht, Myriophyllum tetrandrum Roxb. and Sagittaria guayanensis subsp. lappula (D. Don) Bogin.

\section{Diagnosis}

Halicyclops songsonensis sp. $\mathrm{n}$. can be distinguished from its congeners by the following combination of characters: the round/oval integumental windows present on the dorsal surface of cephalothorax and two next prosomites; genital double-somite with lateral angular protuberances; the dorsal part of frill on pre-anal somite bearing slightly larger denticles than that on lateral and ventral parts; caudal rami relatively long, about 1.43-1.51 times as long as it is wide; fourth segment of antennule elongated, about 2.3-2.4 times as long as wide; the 3:4:4:3 spine formula on the P1-P4 Exp3 and the proximalmost seta on P2-P3 Enp3 modified to spiniform.

\section{Etymology}

Named after the type locality, Son River in Central Vietnam.

\section{Description}

Female. Body (fig. 2A) small, 730-930 $\mu \mathrm{m}$ long (mean $=834 \mu \mathrm{m}, \mathrm{n}=10)$, excluding caudal setae; maximum width about $315 \mu \mathrm{m}$ at posterior end of cephalothorax. Prosome length/width (L/W) about 1.65-1.77 and 1.781.91 times as long as urosomite. Cephalothorax triangular in dorsal view, not strongly protruded anteriorly, nearly as long as wide, with a round integumental window on dorsal surface. Outer distal corners of last two prosomites rounded, gently expanded posteriorly.

Genital double-somite (figs. 2C, E) about 1.06-1.12 times as long as wide, laterally expanded into blunt angular protuberances. 
Seminal receptacle with a big median copulatory pore anteriorly. Hyaline frills of genital double-somite and two subsequent somites serrate. 6-8 middorsal teeth on the dorsal parts of frill of pre-anal somite not strongly produding posteriorly, and slightly larger than that on lateral and ventral parts. Anal somite (fig. 2C) with a row of spinules along ventral and lateral distal margins.

Caudal rami (figs. 2C-D) relatively long, about 1.43-1.51 times as long as wide; distal outer and inner corners with transverse rows. Lateral caudal seta situated dorsally at proximal third of ramus. Dorsal caudal seta 1.4-1.6 times longer than ramus. Inner caudal seta minute, smooth, about 0.4 times as long as ramus. Outer caudal seta pinnate, about 3.0 times as long as inner caudal seta. Outer terminal caudal seta spinulose on outer margin and plumose on inner margin of distal half. Inner terminal caudal seta with proximal half smooth; distal half spinulose proximally and plumose distally.

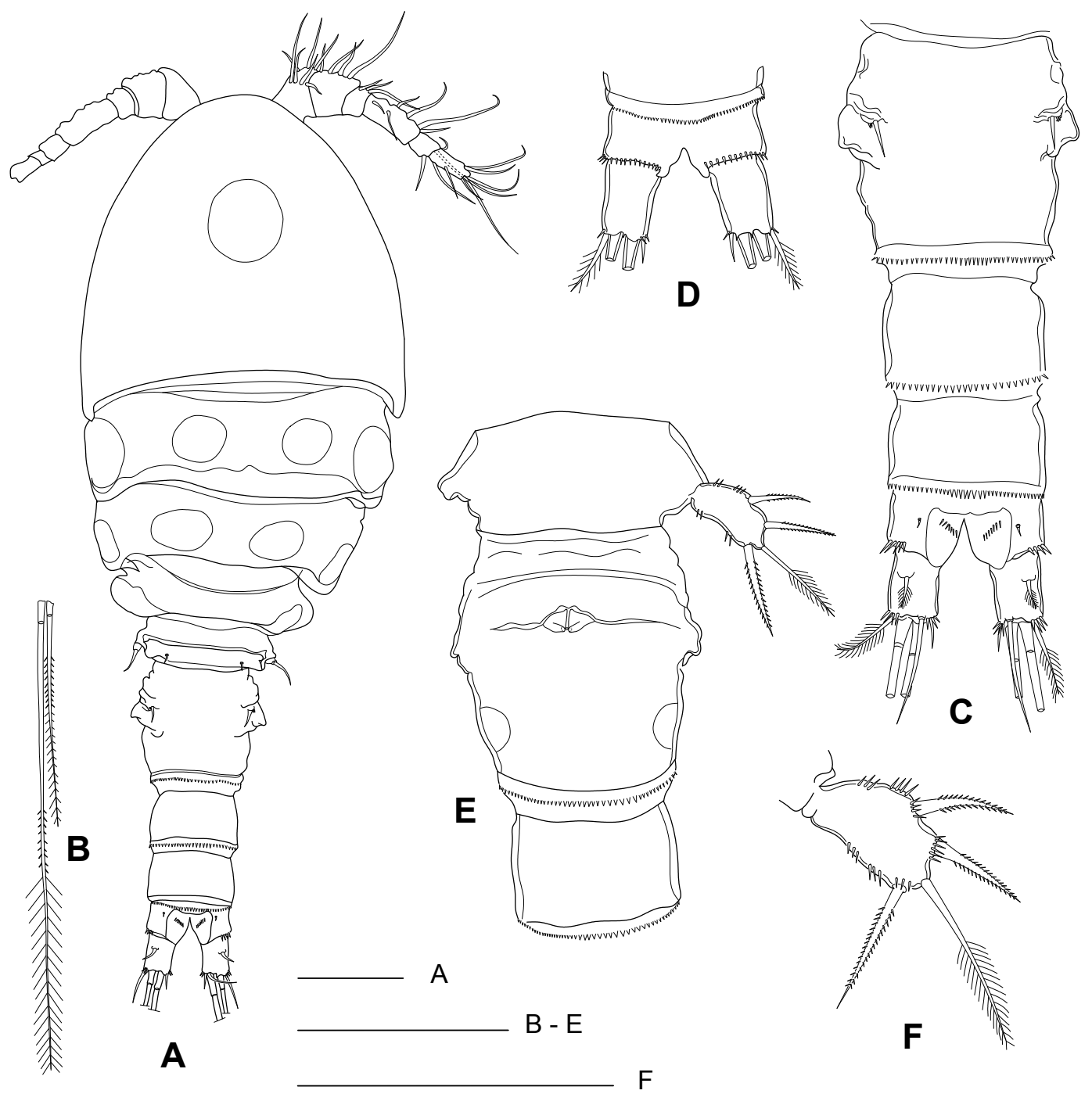

Figure 2. Halicyclops songsonensis sp. n., female. A. Habitus; B. Middle apical caudal setae; C. Urosome, dorsal; D. Anal somite and caudal rami, ventral; E. Pediger 5, genital double-somite and third urosomite, ventral; F. P5. A-B, C, F. Holotype; D-E. Paratype, IEBR-COP3253. Scales: 100 $\mu \mathrm{m}$. 
Antennule (fig. 3A) six-segmented, reaching midlength of cephalosome, with a setal formula of $8,12,5+1$ spines, $6+1$ aesthetasc, 2, 10+1 aesthetasc. Fourth segment about 2.3-2.4 times as long as wide.

Antenna (fig. 3B) three-segmented, consisting of coxobasis and two-segmented endopod. Coxobasis ornamented with 2 pinnate inner distal setae, and 1 outer distal seta representing exopod. First endopodal segment bearing 1 inner seta, with smooth margins lacking spinules. Second endopodal segment about 3.1 times as long as it is wide; ornamented with spinules on caudal face proximally and one small setule row along distal outer margin; armed with 5 inner lateral and 7 apical setae.

Mandible (fig. 3D) with well-developed coxal gnathobase, armed with 6 strong teeth, 4 slender spiniform setae, 1 stout spine and 1 outer distal pinnate seta. Palp strongly reduced, with two unequal setae. Gnathobase with two rows of spinules near palp and base of segment, respectively.

Maxillule (fig. 3E), praecoxal arthrite bearing 4 strong tooth-like spines on apex; inner surface armament consisting of 7 setae. Palp 2segmented; coxobasis bearing 1 spiniform, two setae inner distally and 1 outer pinnate seta representing exopod; distal segment, representing endopod, armed with 3 plumose setae.

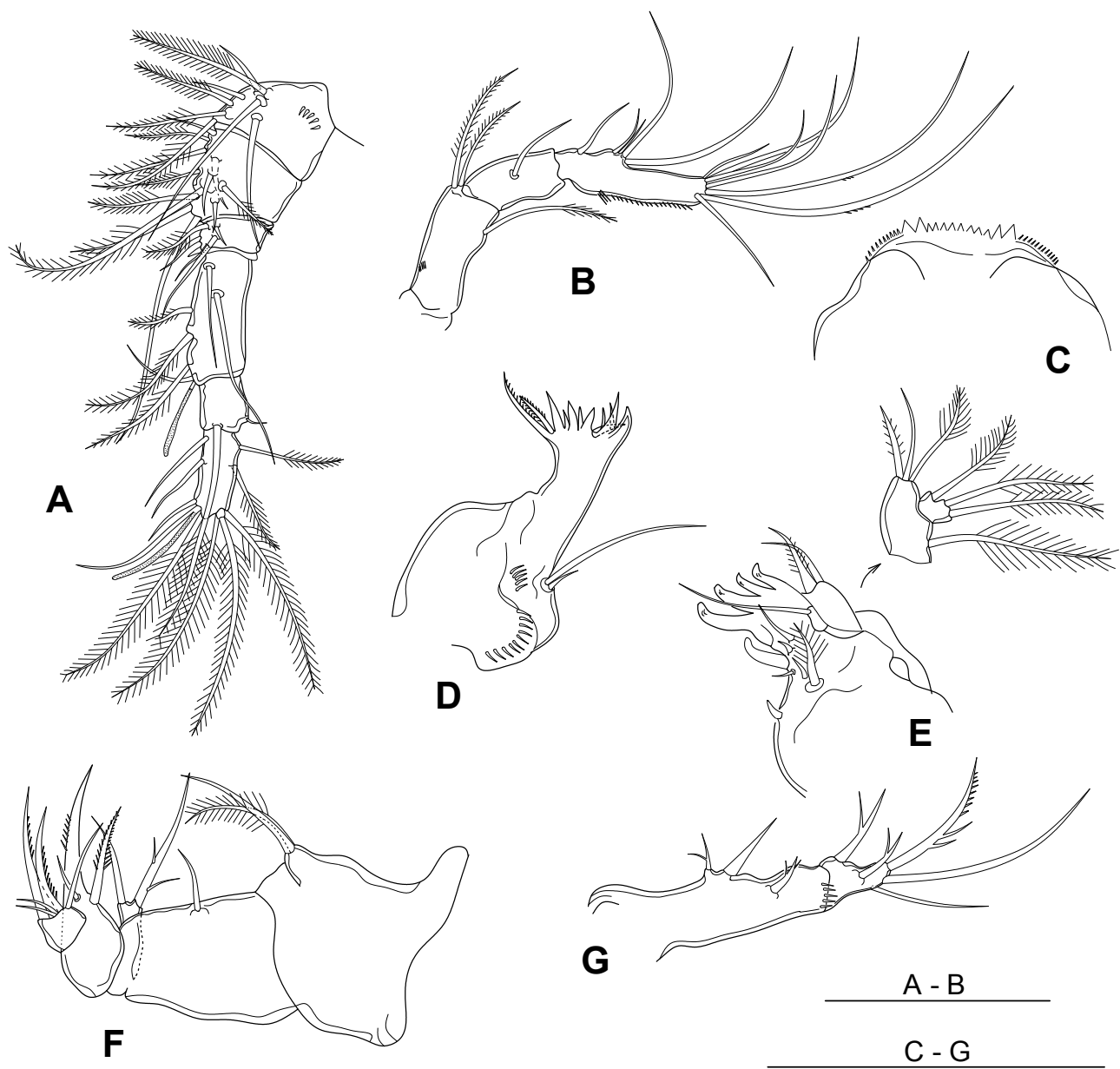

Figure 3. Halicyclops songsonensis sp. n., female (holotype). A. Antennule; B. Antenna; C. Labrum, ventral; D. Mandible; E. Maxillule; F. Maxilla; G. Maxilliped. Scales: $100 \mu \mathrm{m}$. 
Maxilla (fig. 3F) 4-segmented, comprising praecoxa, coxa, basis and 1-segmented endopod. Praecoxa with 2 setae on endite. Coxa with 1 naked seta representing proximal endite; distal endite with strong spine fused to endite and one naked seta proximally. Basis with 1 strong claw-like spines expanding medially, 1 strong toothed spine and 1 medial seta. Endopod with 2 claw-like spines, 1 naked spiniform seta and 2 small setae.

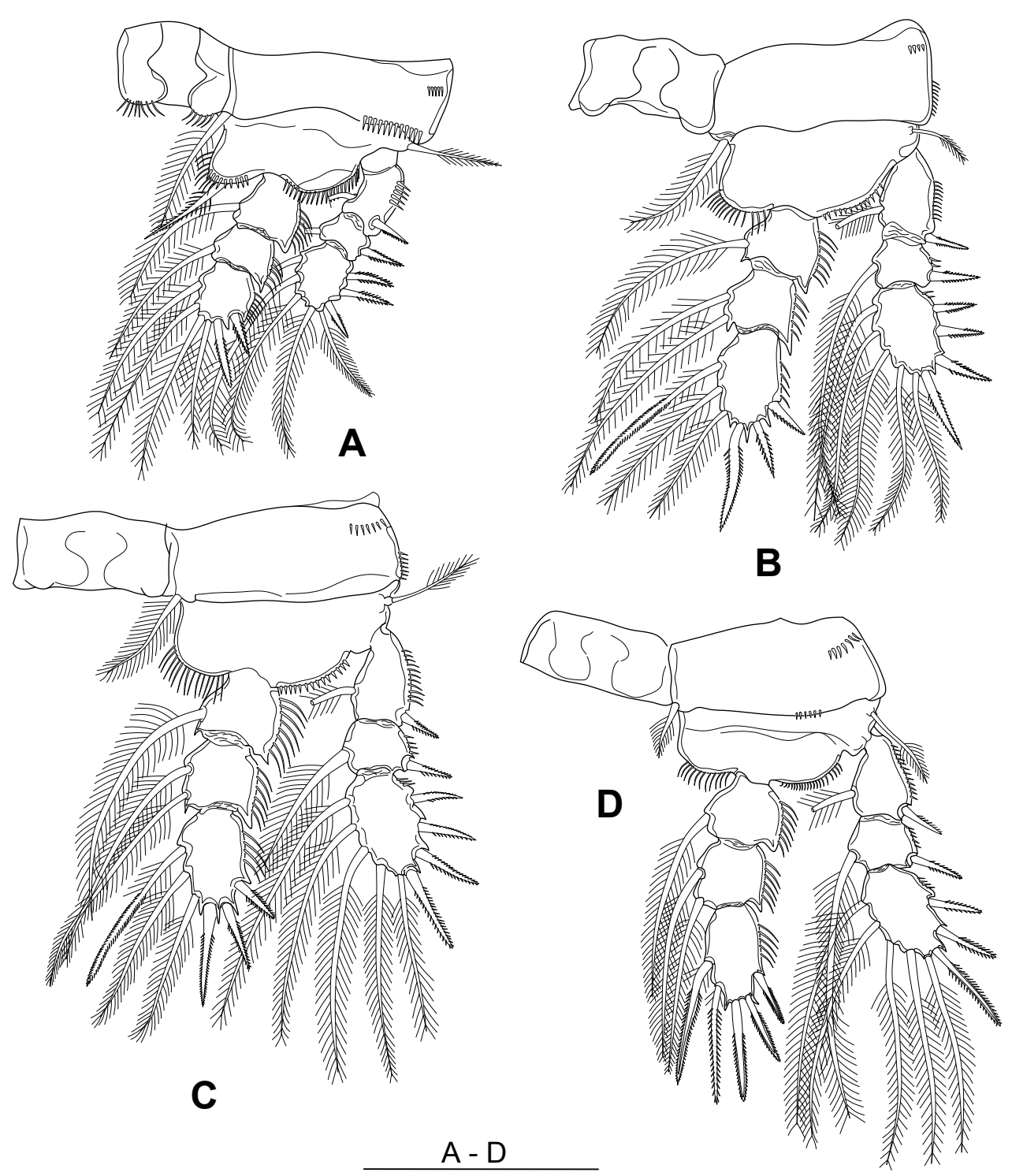

Figure 4. Halicyclops songsonensis sp. n., female (holotype) A. P1; B. P2; C. P3; D. P4. Scale: $100 \mu \mathrm{m}$.
Maxilliped (fig. 3G) 2-segmented; protopod about 3.2 times longer than endopod; protopod with 3 setae on medial side and 1 setule row present on outer distal corner; endopod with 5 setae, comprising 2 inner, 1 apical and 2 outer setae.

P1-P4 (fig. 4A-D) with 3-segmented rami. Coxal setae pinnate. Spine formula of $3: 4: 4: 3$. Setal and spine armature of P1-P4 as in table 1 . 
Table 1. Armature of legs 1-4 in Halicyclops songsonensis sp. n. (Spines are denoted by Roman, setae by Arabic numerals. The armature on the lateral margin of any segment is given first, followed by the elements on the apical and medial margins)

\begin{tabular}{ccccc}
\hline & Coxopodite & Basipodite & Exopodite & Endopodite \\
\hline P1 & $0-1$ & $1-\mathrm{I}$ & I-1; I-1; III-2-4 & $0-1 ; 0-1 ;$ I-I,1-3 \\
P2 & $0-1$ & $1-0$ & I- $1 ;$ I-1; III-I,1-4 & $0-1 ; 0-2 ;$ I-II-3 \\
P3 & $0-1$ & $1-0$ & I-1; I-1; III-I,1-4 & $0-1 ; 0-2 ;$ I-II-3 \\
P4 & $0-1$ & $1-0$ & I-1; I-1; II-I,1-4 & $0-1 ; 0-2 ;$ I-II-2 \\
\hline
\end{tabular}

P1 (fig. 4A) intercoxal sclerite with a row of long hairs along the edge of the round protuberance on each side; basis with medial spine bearing long setules proximally and reaching to tip of second endopodal segment; second lateral spine of third exopodal segment slightly shorter than this segment and about 1.3 times longer than third spine.

P2-P4 (fig. 4B-D) intercoxal sclerites without setules of spinules on distal margin of both lateral lobes; medial expansion of basipodite apically pilose; Enp2 with 2 inner setae. P2-P3 with proximal most seta on Enp3 modified to spiniform. P4 (fig. 4D), Enp3 about 1.5-1.7 times as long as wide; both inner setae spiniform; inner apical spine about 1.1 times longer than Enp3, and 1.3 times longer than outer apical spine.
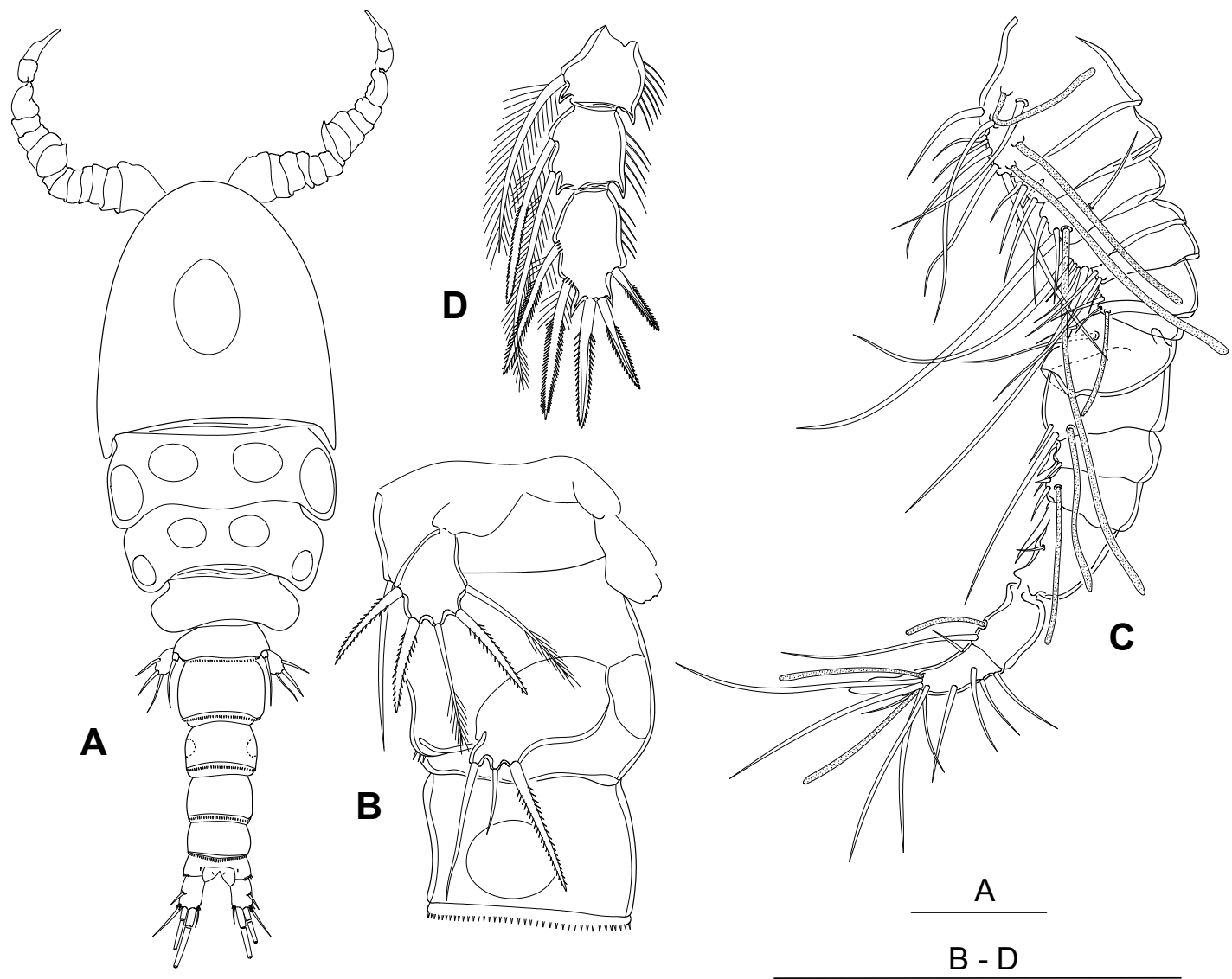

Figure 5. Halicyclops songsonensis sp. n., male (paratype, IEBR-COP3252)

A. Habitus; B. Three first urosomites, showing P5 and P6, lateral;

C. Antennule; D. Endopod of P4. Scales: $100 \mu \mathrm{m}$. 
P5 (fig. 2F) with basis and endopod completely incorporated to fifth pedigerous somite; basal seta inserted on small protuberance arising from dorsolateral corner of somite. Exopod 1.5-1.6 times longer than broad, bearing 3 spines and 1 seta; inner apical spine 0.9-1.0 times as long as exopod segment, 1.11.3 times as long as outer proximal spine and 1.2-1.3 times as long as distolateral spine; terminal seta 1.2-1.4 times as long as segment.

P6 (figs. 2A, C) indistinct, represented by small genital operculum armed with 2 tooth-like spine and 1 long seta.

Male. Body (fig. 5A) smaller and slender than female, 525-570 $\mu \mathrm{m}$ long (mean $=540 \mu \mathrm{m}$, $\mathrm{n}=5$ ). Caudal rami (fig. $5 \mathrm{~A}$ ) about 1.5 times longer than wide; armed with spinules at the outer distal margin of ramus and near base of inner caudal seta. Hyaline fringe of pre-anal somite dentate, not strongly protruding posteriorly; 10-12 middorsal teeth larger than lateral and ventral teeth. Antennule (fig. 5C) 14segmented, with geniculation between segment 12 and segment 13; armed as follows: $8+3$ aesthetasc, 4, 4+1 aesthetasc, 4, 2, 2, 1+1 aesthetasc, 2, 2+1 aesthetasc, $1+1$ spine, 1+1 spine +1 aesthetasc, $1+1$ spine, $1+1$ aesthetasc, $11+2$ aesthetasc. Shape and armature of P1-P4 nearly same as in female, except for inner proximal seta on P4 Enp2 modified to spiniform (fig. 5D). P5 (fig. 5B) oval, 1.2 times longer than wide, with 2 outer spines similar in length each other, 1 apical seta, 1 inner seta, 1 inner apical spine slightly longer than outer spine and 1.1-1.2 times longer than exopod. P6 (fig. 5B) represented by 1 inner spine and 2 setae; outer seta about 3.0 times longer than median seta.

\section{Remarks}

At present, the genus Halicyclops is divided into seven morphological groups according to the number of spines on the distal exopodal segments of P1-P4 (Chang \& Lee, 2012; Pesce, 2016). Halicyclops songsonensis sp. n. can be assigned to the "group B" showing the spine formula P1-P4 of 3:4:4:3. This group currently comprises 75 species and subspecies (Pesce, 2016). Within this group, Halicyclops songsonensis $\mathrm{sp} . \mathrm{n}$. is similar to four species, $H$. soqotranus Baribwegure \& Dumont, 2000 from Soqotra Island (Yemen), H. venezuelaensis Lindberg, 1954 from Venezuela, H. dussarti Rocha, 1995 from Brazil, and H. ambiguus Kiefer, 1967 from Australia by having the genital double-somite with lateral angular protuberances; the dorsal part of frill on preanal somite bearing slightly larger denticles than that on lateral and ventral parts. Among those species, only $H$. dussarti has been found from freshwater habitats. H. soqotranus can be easily distinguished from all its congeners and a new species by the absent of spine on inner distal edge basipodite P1. H. songsonensis differs from two South American species, $H$. venezuelaensis and $H$. dussarti by the length/width ratio of caudal rami (about 1.5 versus 1.0), of P4 Enp3 (about 1.64 versus 1.47 and 1.43 in $H$. venezuelaensis and $H$. dussarti, respectively). Caudal rami of the new species is longer than that of $H$. ambiguus (the length/width ratio is 1.5 in $H$. songsonensis and 1.0 in $H$. ambiguus); an inner spine of $\mathrm{P} 1$ basis reaching to midlength of P1 Enp3 in $H$. ambiguus (versus only reaching to distal border of P1 Enp2 in $H$. songsonensis); P4 Enp3 is shorter in $H$. ambiguus (the length/width ratio is about 1.1-1.2 in H. ambiguus versus 1.64 in the new species) and the form of inner proximal seta in Enp3 of P2-P3 (versus normally plumose seta in $H$. ambiguus and spiniform seta in $H$. songsonensis). On the other hand, $H$. songsonensis is distinguishable from all above species by the presence of oval integumental window on cephalothorax and two next prosomites.

H. songsonensis $\mathrm{sp}$. $\mathrm{n}$. also clearly differs from two other freshwater species, $H$. sinensis Kiefer 1928 from China and H. magniceps (Lilljeborg, 1853) widely distributed in Europe, Africa, China, North America (reported in Vietnam as $H$. aequoreus Fischer, 1860) by the presence of lateral angular protuberances at proximal third of genital double-somite in the new species. Furthermore, genital doublesomite and urosomites of $H$. magniceps have smooth dorsal margins whereas they have serrate hyaline frills in $H$. sinensis and $H$. songsonensis. The caudal rami and the fourth 
segment of antennule in $H$. sinensis are shorter than those in two species, H. magniceps and $H$. songsonensis $\mathrm{sp} . \mathrm{n}$.

In addition, $H$. songsonensis is similar to two brackish water species from estuaries in the Northwest Pacific, H. setiformis Ueda \& Nagai, 2012 from Japan and Korea, and H. continentalis Ueda and Nagai, 2009 from China, Japan, Korea in having angular lateral protuberances of genital-double somite, and the dorsal part of frill of fourth urosomite being less developed than lateral and ventral parts. However, these species are distinguishable from $H$. songsonensis by the spine formula of P1-P4 of $3: 4: 3: 2$ in $H$. setiformis and $3: 4: 3: 3$ in $H$. continentalis; shorter caudal rami (about 1.1 and 1.2 times as long as wide in $H$. setiformis and in $H$. continentalis, respectively versus about $1.43-$ 1.51 times as long as wide in $H$. songsonensis sp. n.); length of fourth segment of antennule in $H$. setiformis (with the length nearly equal to the width) being shorter than that in other species (about 1.4-1.5 times as long as wide in $H$. continentalis and 2.3-2.4 times in the new species); the spine on inner margin of $\mathrm{P} 1$ basis reaching to top of $\mathrm{P} 1 \mathrm{Enp} 3$ in $H$. setiformis and $H$. continentalis, but reaching only to the distal margin of $\mathrm{P} 1$ Enp2 in $H$. songsonensis sp. n.; and denticules of mid-dorsal frill of fourth urosomite slightly larger in $H$. continentalis.

Acknowledgments: This research is funded by the Vietnam National Foundation for Science and Technology Development (NAFOSTED) under grant number 106-NN.05-2013.13. We would like to deeply thank Dr. Nguyen The Cuong (IEBR) for the identification of the aquatic plants.

\section{REFERENCES}

Baribwegure D., Dumont H. J., 2000. Some freshwater cyclopoids (Crustacea: Copepoda) of the Island of Soqotra (Indian Ocean), with the description of three new species. International Review of Hydrobiology, 85(4): 471-489.

Burckhardt G., 1913. Wissenschaftlich Ergebnisse einer Reise um die Erde von M. Pernod und C. Schröter. III. Zooplankton aus ost- und süd-asiatischen Binnengewässern. Zoologische Jahrücher, Abteilung für Systematik, Ökologie und Geographie, 34: 341-472, pls. 9-17.

Chang C. Y., 2012. Discovery of Halicyclops continentalis (Cyclopidae, Halicyclopinae) from estuaries and salt marshes on the west coast of South Korea. Animal Systematics, Evolution and Diversity, 28(1):12-19.

Chang C. Y., Lee J., 2012. Two new species of Halicyclops (Cyclopoida, Cyclopidae) from the estuarine interstitial waters in South Korea. Zootaxa, 3368: 197-210.

Ho Thanh Hai, Tran Duc Luong, 2007. To add six new species freshwater crustaceans (Cyclopoida, Harpacticoida-Copepoda) to the fauna of inland freshwater zooplankton of Vietnam. Tap chi Sinh hoc, 29(2): 9-16.

Huys R., Boxshall G. A., 1991. Copepod evolution. The Ray Society, London, pp. 1468.

Kiefer F., 1928. Beitrage zur Copepodenkunde (VII). Zoologischer Anzeiger, 110: 10-13.

Kiefer F., 1967. Cyclopiden aus salzhaltigen Binnengewässern Australiens (Copepoda). Crustaceana, 12(3): 292-302.

Lee J., Chang C. Y., 2013. Halicyclops copepods (Cyclopidae, Halicyclopinae) from Korea. Animal Systematics, Evolution and Diversity, 29(1): 36-50.

Pesce G. L., 2016. Cyclopoida: Halicyclopinae Kiefer, 1927: Halicyclops Norman, 1903. Copepod Web Portal. Available at http:// www.luciopesce.net/copepods/halicyc.htm/ on 15 October 2016.

Rocha C. E. F. da, 1995a. Copepods of the genus Halicyclops (Cyclopidae) from Belize. Hydrobiologia, 308(1): 1-11.

Rocha C. E. F. da, 1995b. Two new species of Halicyclops (Copepoda, Cyclopoida) from the Amazon Basin, Brazil. Hydrobiologia, 315(3): 167-175.

Tai A. Y., Chen G. X., 1979. Cyclopoida Sars, 1886. In: Shen C. J. and Fauna Editorial Committee (eds.) Freshwater Copepoda. 
Fauna Sinica, Crustacea. Science Press, Beijing, pp. 301-420 (in Chinese).

Ueda H., Nagai H., 2009. Three new species of the brackish water copepod Halicyclops (Crustacea, Cyclopoida) from Ariake Bay, Japan. Journal of Natural History, 43(5-6): 287-307.

Ueda H., Nagai H., 2012. Two new species of Halicyclops (Crustacea: Copepoda:
Cyclopidae) from Honshu with a key to the species of the genus in Japan. Species Diversity, 17: 97-107.

Walter T. C., Boxshall G., 2015. Halicyclops Norman, $1903 . \quad$ In: Walter T.C. \& Boxshall G. (2016). World of Copepods database. Available at http://www.marinespecies.org/aphia.php?p= taxdetails\&id=106433 on 15 October 2016.

\title{
MộT LOÀI GIÁP XÁC CHÂN CHÈO NƯớC NGỌT MỚI THUỘC GIỐNG Halicyclops (Copepoda, Cyclopoida, Cyclopidae) TỪ MIỀN TRUNG VIẸTT NAM
}

\author{
Trần Đức Lương ${ }^{1}$, Lê Danh Minh ${ }^{2}$, Hồ Thanh Hải ${ }^{1}$ \\ ${ }^{1}$ Viện Sinh thái và Tài nguyên sinh vật, Viện Hàn lâm KH \& CN Việt Nam \\ ${ }^{2}$ Trường Đại học Hà Tĩnh
}

\section{TÓM TẮT}

Một loài giáp xác chân chèo nước ngọt mới thuộc giống Halicyclops, H. songsonensis Tran, Le \& Ho, sp. n. được mô tả từ các mẫu vật thu thập ở sông Son, tỉnh Quảng Bình, miền Trung Việt Nam. Loài mới H. songsonensis $\mathrm{sp}$. $\mathrm{n}$. khác với các loài gần gũi bởi sự kết hợp của các đặc điểm sau: công thức gai cứng đốt 3 nhánh ngoài chân I-IV là 3:4:4:3; đốt sinh dục có một mấu lồi dạng tam giác, tròn đầu ở mỗi bên; gờ trong suốt mép sau đốt bụng thứ tư khía răng cưa, các gai ở phần giữa mặt lưng chỉ hơi lớn hơn các gai ở mặt bên và mặt bụng; chạc đuôi tương đối dài; đốt 3 nhánh trong chân II-III có tơ gần gốc mép trong dạng gai; đầu và hai đốt ngực theo sau có các lỗ mở hình oval hoặc tròn.

Tì khóa: Giáp xác chân chèo, phân loại học, loài mới, nước ngọt. 